\title{
Sprawozdanie z konferencji Muzea i organizacje pozarzqdowe. Budowanie relacji, szanse i zagrożenia
}

W dniach 6 i 7 października 2016 r. w Muzeum Wsi Mazowieckiej w Sierpcu odbyła się konferencja pod tytułem Muzea i organizacje pozarzq̨dowe. Budowanie relacji, szanse i zagrożenia. Konferencje w Sierpcu cieszą się od lat dużym zainteresowaniem ze strony zarówno środowisk akademickich, jak i muzealnych. Różnorodność oraz aktualność podejmowanych w ramach tych spotkań tematów, daje możliwość przedstawienia rozmaitych stanowisk i podjęcia jakże ważnej dyskusji.

W tym roku tematem spotkania była współpraca muzeów z organizacjami pozarządowymi. Uczestniczyli w nim muzealnicy, członkowie organizacji pozarządowych i ośrodków naukowych oraz kolekcjonerzy z całego kraju. Podczas dwóch dni obrad poruszone zostały tematy związane z możliwościami jakie daje kooperacja tych dwóch sektorów, ale też o zagrożeniach jakie czasami ze sobą niesie, o ich wzajemnych wpływach oraz najciekawszych inicjatywach społecznych ożywiających i wzbogacających muzealne kolekcje, ofertę edukacyjną i ekspozycje.

Katarzyna Barańska z Uniwersytetu Jagiellońskiego w swoim referacie $M u$ zea i organizacje pozarzq̨dowe. W poszukiwaniu dobra wspólnego starała się odpowiedzieć na pytania: „Czy dziedzictwo jest dobrem wspólnym?”, „Jakie warunki muszą być spełnione by takim się stało?” i „Jakie rodzaje wspólnot to obejmuje?”. Przedmiotem jej analizy stała się współpraca pomiędzy małym lokalnym muzeum i stowarzyszeniem działającym w Krakowie.

Jan Święch z Uniwersytetu Jagiellońskiego w wystąpieniu Między stanem idealnym a destrukcja. Współpraca organizacji pozarzq̨dowych z samorzq̨ami na przykładzie Stowarzyszenia Muzeów na Wolnym Powietrzu poruszył kwestię kwalifikacji osób oddelegowanych przez samorządy do współpracowania z organizacjami pozarządowymi. Na początku, gdy podejmowane były pierwsze kroki w tym zakresie, osoby, które miały współpracować z muzeami, były przygotowywane merytorycznie. Wszystkie podjęte kroki miały zapewnić jak najlepsze współdziałanie z tym sektorem. Niestety w ostatnich latach zaczęły zachodzić zmiany, a osoby przydzielane do tych zadań nie posiadają już niezbędnych kwalifikacji. Aby taka relacja była owocna i miała pozytywny wpływ, muszą zajmować się nią osoby posiadające niezbędną wiedzę. 
Teresa Lasowa z Towarzystwa Przyjaciół Muzeum Kaszubskiego Parku Etnograficznego we Wdzydzach Kiszewskich w opracowaniu Działalność Towarzystwa Przyjaciół Muzeum-KPE we Wdzydzach Kiszewskich w latach 19932016 zwróciła uwagę na to, że polskie muzealnictwo skansenowskie wyrosło w tradycji europejskich nurtów ochrony rodzimej kultury. Bez wsparcia i współdziałania z lokalnymi społecznościami, wśród których i dla których działa, nie mogło być to możliwe. Szlachetna nieformalna pomoc społeczników przybierała w różnym czasie różnorodne formy. Pokazała to na przykładzie bogatej historii muzeum we Wdzydzach. Towarzystwo Przyjaciół Muzeum jako organizacja pozarządowa troszczy się o jego potrzeby i wspiera działalność muzeum. Przez 23 lata pracy grupy społeczników zrealizowano wiele ważnych inicjatyw w postaci prac konserwatorskich, wystaw, plenerów i imprez, co przyczyniło się do znaczącego rozwoju placówki.

Marta Bloch-Pogodzińska z Ideatorium Centrum Naukowo-Edukacyjnego wraz z Aleksandrem Piaseckim z Uniwersytetu Rzeszowskiego oraz Pawłem Markiem Pogodzińskim z Muzeum Archeologicznego w Gdańsku w prelekcji Organizacje pozarzq̨dowe jako twórcy instytucji kultury o tematyce archeologicznej. Szansa czy zagrożenie dla zabytków zwrócili uwagę na zagrożenia i szkody jakie dla zabytków może przynieść ta współpraca. Pokazali jak stanowiska archeologiczne stają się potencjalnym motorem napędowym lokalnej turystyki w wielu miejscowościach Polski. Tworzące się zrzeszenia, główny cel swojej działalności upatrują w stworzeniu miejscowej atrakcji, której głównym tematem będzie archeologia. Na podstawie kilku tego typu przykładów z terenu Polski ukazali zarówno zalety, jak i wady takiej kooperacji. Niestety zauważyli, że tych ostatnich zaczyna przybywać. Organizacje te często są pozbawione wsparcia merytorycznego, a ich działania są raczej przypadkowe i dowolne. Prowadzi to do tworzenia instytucji często fałszujących obraz przeszłości odkrywany przez badacza.

Damian Kasprzyk z Uniwersytetu Łódzkiego w swoim referacie Forma w służbie pasji. Alians Muzeum Komunikacji Miejskiej w Łodzi z Klubem Miłośników Starych Tramwajów zaprezentował działania podejmowane przez Klub Miłośników Starych Tramwajów w kooperacji z Muzeum Komunikacji w Łodzi, które podlega działowi promocji Miejskiego Przedsiębiorstwa Komunikacyjnego. Ukazał funkcje tych instytucji oraz formy ich współpracy.

Paweł Marek Pogodziński z Muzeum Archeologicznego w Gdańsku w swoim wystąpieniu Współpracy Grodziska w Sopocie z organizacjami pozarzq̨dowymi - między potrzebq a koniecznościq pokazał w jaki sposób odbywa się współdziałanie z tzw. trzecim sektorem w placówce, którą reprezentuje. Podkreślił, że czasem jest ona wymuszona i nie zawsze wspomaga działania muzeum.

Magdalena Grassmann z Muzeum Historii Medycyny i Farmacji Uniwersytetu Medycznego w Białymstoku wraz z Hubertem Kowalskim z Muzeum Uniwersytetu Warszawskiego oraz Markiem Bukowskim z Muzeum Gdańskiego Uniwersytetu Medycznego w referacie Muzea uczelniane i organizacja pozarzqdowa - zbudowane relacje, nowe szanse i zero zagrożeń zaprezentowali działalność muzeów uczelnianych, których rola jest niezmienna. Mają chronić i kultywować dziedzictwo akademickie i historię nauki. Ukazali na przykładzie kilku 
placówek jakie możliwości działania otwiera kooperacja, a w szczególności stowarzyszenia działające przy muzeum. W środowisku polskich muzeów uczelnianych swoistym łącznikiem między światem akademickim a społeczeństwem jest powołane w 2014 roku Stowarzyszenie Muzeów Uczelnianych. Stowarzyszenie to od samego początku scala większość z nich, a jego głównym celem jest praca na rzecz rozwoju muzeów funkcjonujących w strukturach uczelni. Aktywna działalność Stowarzyszenia nie tylko na rynku krajowym, ale również międzynarodowym sprawia, że przed rodzimymi muzeami rodzą się nowe szanse i możliwości w zakresie współpracy naukowej.

Magdalena Grassmann oraz Marta Piszczatowska z Muzeum Historii Medycyny i Farmacji Uniwersytetu Medycznego w Białymstoku w szkicu Muzea uczelniane a organizacje pozarzq̨dowe na przykładzie Muzeum Historii Medycyny i Farmacji Uniwersytetu Medycznego w Białymstoku zwróciły uwagę, że muzea uczelniane dokumentują dziedzictwo nauki, stanowiąc rodzaj łącznika między światem akademickim a społeczeństwem. Ich głównym celem jest ochrona i kultywowanie uniwersyteckiej spuścizny oraz edukowanie społeczeństwa w zakresie rozwoju nauki na przestrzeni dziejów. Od początku placówki tego typu stanowiły bardzo atrakcyjną przestrzeń służącą ukazywaniu rozwoju badań. Obecnie, w swoistej „erze muzeów”, muzea uczelniane stanowią liczną grupę. W swojej pracy bardzo często opierają się na współdziałaniu z organizacjami pozarządowymi.

Jerzy Piotrowski z Muzeum Wsi Mazowieckiej w Sierpcu w swoim referacie Muzea a organizacje pozarzqdowe: synergia, symbioza, mutalizm czy protokooperacja? zaprezentował przykłady współpracy, jakie mają miejsce między Muzeum Małego Miasta w Bieżuniu oddziałem Muzeum Wsi Mazowieckiej a zrzeszeniami działającymi w Bieżuniu. Duże wsparcie dla przedsięwzięć Muzeum pochodzi również od samych mieszkańców, którzy licznie uczestniczą w organizowanych przez nie inicjatywach.

Aleksandra Maria Janowska z Uniwersytetu Mikołaja Kopernika w Toruniu w prelekcji Muzea indiańskie - plemienna autokreacja czy obiektywne źródło wiedzy? Problem finansowania placówek muzealnych ze środków pochodzqcych m.in. z indiańskich kasyn przedstawiła te indiańskie plemiona, które dzięki otwarciu domów hazardu mogły pozyskane środki przeznaczyć nie tylko na tworzenie muzeów, ale również różnego rodzaju pomoc dla współplemieńców. Dzięki temu wsparciu możliwy stał się rozwój placówek muzealnych. Niektóre wystawy poprzez użycie różnych nowinek technologicznych wyglądają bardzo realistycznie, lecz łatwo w popaść w tym miejscu w przerysowanie.

Agnieszka Szostak z Muzeum Historycznego Miasta Krakowa w swoim wystąpieniu Formy współpracy muzeów z organizacjami pozarzq̨dowymi na przykładzie wybranych muzeów krakowskich omówiła współpracę Muzeum Historycznego i Towarzystwa Pro Museo, założonego z inicjatywy pracowników Muzeum w roku 1996. Przedstawiła charakter kooperacji, obszary wspólnych działań oraz realizowane projekty. Na podstawie udostępnionych materiałów oraz wywiadów, przeprowadzonych z pracownikami Muzeum oraz przedstawicielami 
Zarządu Stowarzyszenia, zestawiła ich spojrzenie na wzajemne relacje. Charakterystyka współdziałania została porównana z analogiczną aktywnością Muzeum Narodowego w Krakowie oraz Towarzystwa Przyjaciół Muzeum Narodowego w Krakowie - jednego z najstarszych tego typu stowarzyszeń w Polsce, powstałego w 1903 roku. W konkluzji starała się scharakteryzować możliwe formy interakcji pomiędzy publicznymi instytucjami kultury a sektorem pozarządowym.

Ryszard Kruk ze Stowarzyszenia Przyjaciół „Almanachu Muszyny” w swoim referacie Muzea a organizacje pozarzq̨dowe czyli dylemat zwycięzców spod Wiednia: kto pierwszy powinien uchylić rąbek kapelusza przekonywał, że organizacje pozarządowe, szczególnie te działające w sferze kultury, powinny być najbliższymi partnerami muzeów. Na przykładzie Muszyny i Sądecczyzny pokazał jak taka kooperacja może wyglądać i co udało się w regionie dzięki niej dokonać. Poruszył też problem prywatnych kolekcjonerów i ich kolekcji, które powinny być poddane digitalizacji w celu ułatwienia lokalizacji konkretnych przedmiotów, umożliwienia ich wypożyczenia instytucjom muzealnym i uniknięcia ich rozproszenia po śmierci właściciela. Zaapelował przy tym o zacieśnienie relacji muzeów z osobami gromadzącymi zbiory.

Bogusław Kosel z Muzeum Historii Medycyny i Farmacji Uniwersytetu Medycznego w Białymstoku w wystąpieniu Rola trzeciego sektora w kreowaniu pamięci zbiorowej o wydarzeniach lat 1939-1956 na Podlasiu przybliżył historię tego regionu. W okresie drugiej wojny światowej przejściowo znajdował się w rękach dwóch okupantów - sowieckiego i niemieckiego, a po oficjalnym zakończeniu działań wojennych przez ponad dekadę stanowił miejsce aktywnego działania podziemia niepodległościowego. Pamięć zbiorowa o wydarzeniach lat 19391956 jest na tamtym terenie wyjątkowo żywa, co wynika wprost ze skali represji jakie w tamtym okresie wymierzone były w ludność cywilną. Trudno jest znaleźć na tym obszarze rodzinę, która nie doświadczyłaby strat ze strony okupantów czy powojennych władz. Drugą kwestią wpływającą na aktualność zagadnień historycznych we współczesnym życiu mieszkańców Podlasia jest pamięć o zróżnicowanych postawach ludności względem okupantów - począwszy od czynnego oporu aż po kolaborację. Ukazał wybrane inicjatywy organizacji pozarządowych z obszaru województwa podlaskiego, których celem było upamiętnienie najważniejszych wydarzeń z tamtego czasu związanych z uwzględnieniem represyjnej polityki okupantów, jak również działalności podziemia niepodległościowego.

Katarzyna Dypa z Muzeum Kultury Ludowej w Kolbuszowej w referacie Droga współpracy organizacji pozarzqdowych w Muzeum Kultury Ludowej w Kolbuszowej zaprezentowała jak układała się współdziałanie muzeum ze zrzeszeniami. Podkreśliła, że niektóre inicjatywy bez ich wsparcia trudno byłoby zorganizować, a muzeum czerpie wielkie korzyści z tego partnerstwa.

Podczas obrad referenci pokazali, że muzea i organizacje pozarządowe z nimi związane są dla siebie równoprawnymi partnerami zyskującymi wiele na współpracy. Konferencja stanowiła też szansę na wymianę doświadczeń. To istotne, gdyż placówki muzealne muszą się nieustannie zmieniać, dostosowując swoją ofertę do potrzeb współczesnego odbiorcy, a interakcja ze stowarzyszeniami wydaje się niezbędnym elementem tych działań. Niezwykle cenne były 
także głosy, które zwracały uwagę na potrzebę głębszego merytorycznego przemyślenia niektórych poczynań. Nie każda forma współpracy między muzeum a stowarzyszeniem gwarantować musi sukces.

$\mathrm{Z}$ treścią wszystkich wystąpień będzie się można zapoznać w numerze „Rocznika Muzeum Wsi Mazowieckiej w Sierpcu”, który ukarze się w listopadzie 2017 roku.

\section{Ewa Kaliszewska}

Muzeum Wsi Mazowieckiej w Sierpcu 